\title{
Haemodynamic response to dopexamine hydrochloride in postinfarction heart failure: lack of tolerance after continuous infusion
}

\author{
G SVENSON, L-E STRANDBERG, B LINDVALL, L ERHARDT \\ From the Section of Cardiology, Department of Medicine, Karolinska Institute, Danderyd Hospital, \\ Danderyd, Sweden
}

SUMMARY Dopexamine is a new vasodilator with a combination of dopamine receptor and $\beta_{2}$ adrenoreceptor agonist properties. Its haemodynamic effects were assessed after dose titration and during infusion for up to 24 hours in 15 patients with heart failure after acute myocardial infarction. At the initial titration a dose of $1 \mu \mathrm{g} / \mathrm{kg} / \mathrm{min}$ produced a $25 \%$ decrease in the systemic vascular resistance index and a 32\% increase in cardiac index. Stroke volume index and heart rate increased by $23 \%$ and $9 \%$ respectively. Left ventricular filling pressures and mean blood pressures were not affected. The short term effects were well sustained during the long term infusion and tolerance did not develop.

Administration of dopexamine to patients with heart failure after acute myocardial infarction augments cardiac performance at rest.

Heart failure is a common complication after acute myocardial infarction with a bad prognosis. ${ }^{1-3}$ Treatment is given to improve the depressed left ventricular function and thereby reduce symptoms, to improve exercise capacity, and to improve outcome. In the short term, improvement of cardiac function is most important. This can be achieved either by stimulating the cardiac contractile reserve $e^{4-7}$ and/or by reducing preload and afterload. .10 $^{-10}$ Potent inotropic agents may, however, cause further cardiac metabolic deterioration by increasing oxygen demand ${ }^{1011}$ and their usefulness may be limited by tachycardia and induced arrhythmias. ${ }^{12}$ Reduction of raised systemic vascular resistance is haemodynamically helpful to the failing heart, and vasodilator treatment has gained acceptance in the management of pump failure in patients with acute myocardial infarction. ${ }^{913}$ Intravenous vasodilators with a rapid onset of action and short half life are better in the acute stage of heart failure.

Dopexamine, a novel substance derived from dopamine, has the properties of both a postjunctional dopamine receptor agonist and a $\beta_{2}$ adrenoreceptor agonist. ${ }^{14}{ }^{15}$ Stimulation of these receptors by dopexamine induces renal and mesenteric vasodilatation

Requests for reprints to Dr G Svenson, Department of Medicine, Danderyd Hospital, S-182 88 Danderyd, Sweden.

Accepted for publication 12 August 1988 and peripheral vasodilatation particularly in skeletal muscle. The main haemodynamic effects of dopexamine as demonstrated in studies of animals, ${ }^{16}$ volunteers and patients with chronic heart failure ${ }^{17-20}$ are an increase in cardiac output and ejection fraction, a fall in system vascular resistance, and a mild positive inotropic effect. There is also indirect evidence of a diuretic effect equal to that of equivalent doses of dopamine. In addition to the above direct, receptor mediated pharmacological effects dopexamine is a potent, competitive inhibitor of the neuronal reuptake of catecholamines (uptake 1). ${ }^{21}$

We studied the haemodynamic effects and safety of dopexamine after dose titration and during the first 24 hours of treatment in patients with acute left ventricular failure after acute myocardial infarction. We also studied whether tolerance had developed by repeating the dose titration after the end of the infusion.

\section{Patients and methods}

\section{PATIENTS}

We studied 15 patients (eight men, seven women; mean age 66 years, range 45-75). Table 1 shows data on the patients, the infarct size and location, the time between admission and haemodynamic recordings, and the current treatment. Two patients (cases 2 and 9) had a history of heart failure. All patients had a 


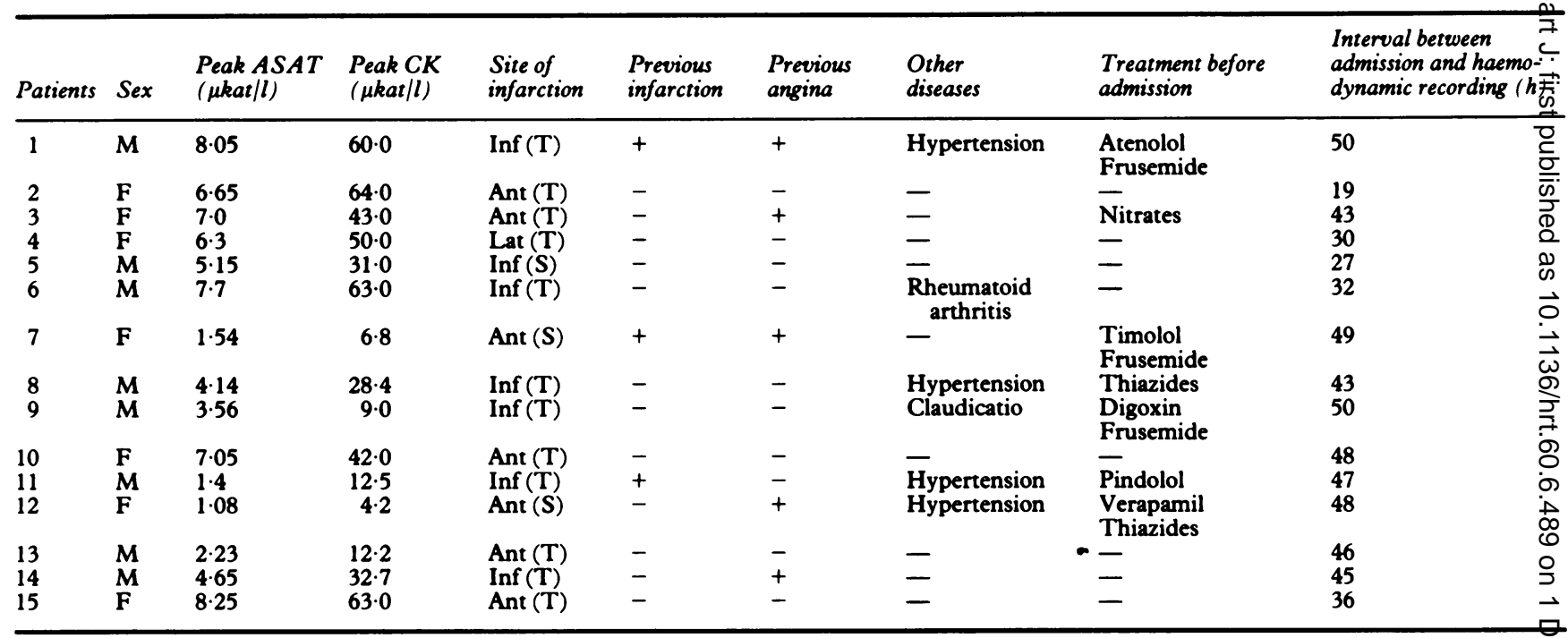

ASAT, aspartate aminotransferase; CK, creatine kinase; Ant, anterior; Inf, inferior; Lat, lateral; (T), transmural; (S), subendocardial. Normal values (lor ASAT $\leqslant 0.7$, CK $\leqslant 2.9$ (female), $\leqslant 2.4$ (male) $\mu \mathrm{kat} / 1$.

recent myocardial infarction as shown by symptoms, enzyme and electrocardiographic changes. All patients also had signs of cardiac failure such as dyspnoea, a third heart sound, basal rales, respiratory rate over 20 beats $/ \mathrm{min}$, or a chest radiogram that was compatible with left heart failure and required diuretics (frusemide) after admission. They were all haemodynamically stable and in sinus rhythm.

Whenever possible no medication other than the trial treatment was given during the study. No medication was given within two hours of the start of the infusion, and patients who had received $\beta$ adrenoreceptor antagonists within 48 hours of the study were excluded. Vasodilating agents were not given after admission.

The protocol was approved by the medical ethics committee of the Karolinska Hospital and all patients gave their informed consent.

\section{HAEMODYNAMIC MEASUREMENTS}

Twelve to $\mathbf{5 0}$ hours after admission to the coronary care unit each patient had a right heart catheterisation with a balloon tipped thermodilution SwanGanz catheter which was floated into the pulmonary

\begin{tabular}{|c|c|c|c|c|}
\hline $\begin{array}{l}\text { Baseline } \\
\text { period }\end{array}$ & $\begin{array}{l}\text { Dose titration 1) } \\
\text { (control 1) }\end{array}$ & $\begin{array}{l}\text { Long term } \\
\text { infusion }\end{array}$ & $\begin{array}{l}\text { Baseline } \\
\text { period }\end{array}$ & $\begin{array}{c}\text { Dose titration } 2 \\
(\text { control 2) }\end{array}$ \\
\hline
\end{tabular}

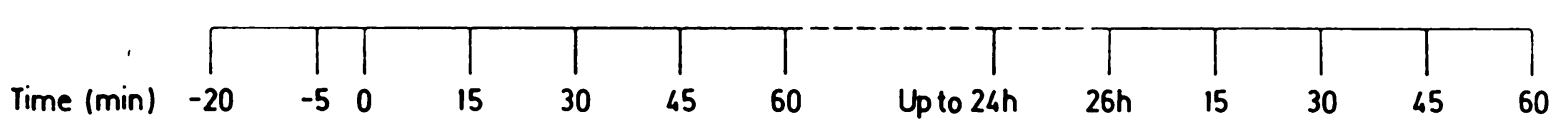

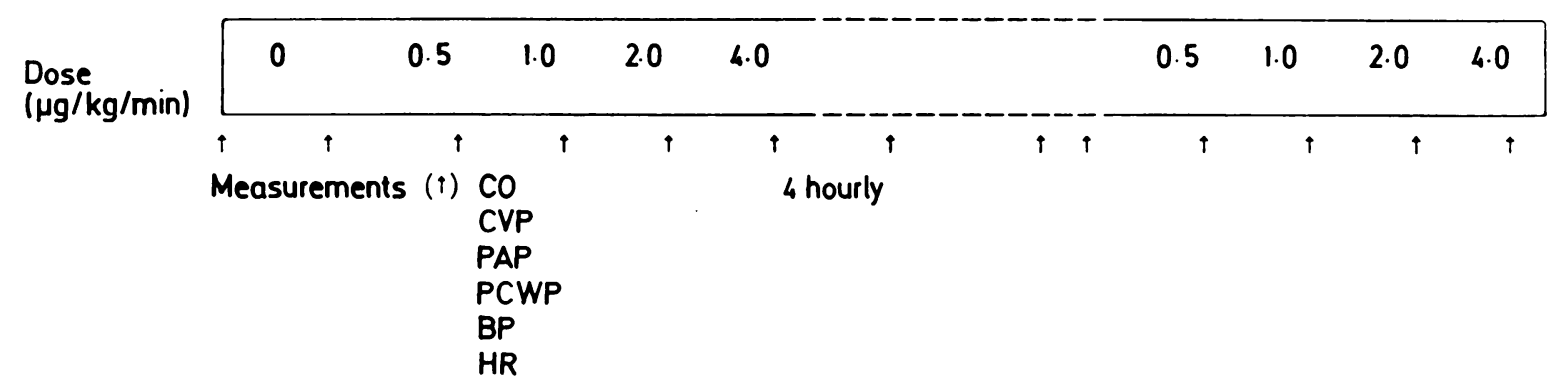

Fig 1 Study design and measured variables in patients with heart failure after acute myocardial infarction. $C O$, cardiac output; CVP, central venous pressure; PAP, pulmonary arterial pressure; $P C W P$, pulmonary capillary wedge pressure; $B P$, blood pressure; $H R$, heart rate. 
Table 2 Haemodynamic data from the initial dose titration (phase 1)

\begin{tabular}{|c|c|c|c|c|c|c|}
\hline \multirow{2}{*}{$\begin{array}{l}\text { Haemodynamic } \\
\text { variable }\end{array}$} & \multicolumn{3}{|c|}{ Infusion rate ( $\mu g / \mathrm{kg} / \mathrm{min})$} & \multirow{2}{*}{$\begin{array}{l}\text { Standard } \\
\text { deviation }\end{array}$} & \multirow{2}{*}{$\begin{array}{l}\text { Significance } \\
(p)\end{array}$} & \multirow{2}{*}{$\begin{array}{l}L S D \\
(0.05)\end{array}$} \\
\hline & 0 & 0.5 & $1 \cdot 0$ & & & \\
\hline 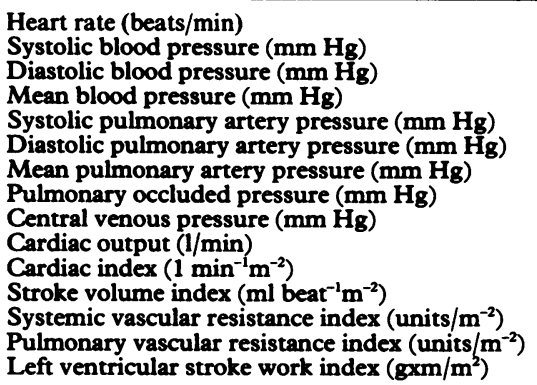 & $\begin{array}{l}79 \\
116 \\
72 \\
87 \\
34 \\
17 \\
22 \\
15 \\
6 \\
3.68 \\
2.01 \\
25 \cdot 6 \\
41 \cdot 6 \\
3.55 \\
24 \cdot 5\end{array}$ & $\begin{array}{c}81 \\
121 \\
71 \\
88 \\
35 \\
16 \\
22 \\
14 \\
6 \\
4 \cdot 22 \\
2 \cdot 31 \\
28 \cdot 6 \\
36 \cdot 1 \\
3 \cdot 25 \\
28 \cdot 2\end{array}$ & $\begin{array}{c}86 \\
122 \\
72 \\
88 \\
37 \\
17 \\
23 \\
15 \\
6 \\
4 \cdot 91 \\
2 \cdot 66 \\
31.5 \\
31 \cdot 3 \\
2.92 \\
31.0\end{array}$ & $\begin{array}{l}\cdot 51 \\
5 \cdot 68 \\
4 \cdot 77 \\
4 \cdot 61 \\
2 \cdot 18 \\
1 \cdot 28 \\
1 \cdot 40 \\
1 \cdot 78 \\
0 \cdot 774 \\
0 \cdot 317 \\
0 \cdot 159 \\
2 \cdot 25 \\
3 \cdot 71 \\
0 \cdot 412 \\
3 \cdot 71\end{array}$ & $\begin{array}{l}<0.001 \\
<0.05 \\
\text { NS } \\
\text { NS } \\
<0.01 \\
\text { NS } \\
\text { NS } \\
\text { NS } \\
\text { NS } \\
<0.001 \\
<0.001 \\
<0.001 \\
<0.001 \\
<0.05 \\
<0.01\end{array}$ & $\begin{array}{l}2.97 \\
4.80 \\
4.03 \\
3.90 \\
1.84 \\
1.08 \\
1.18 \\
1.91 \\
0.654 \\
0.268 \\
0.135 \\
1.90 \\
2.99 \\
0.441 \\
3.14\end{array}$ \\
\hline
\end{tabular}

LSD, Least significant difference.

artery. All measurements were made with the midaxillary line as the zero reference level and with the patient in a supine position. Right atrial and pulmonary artery pressures were monitored continuously. Cardiac output was measured three times by a WTI holland Mc 401 thermodilution cardiac output computer. Left ventricular filling pressures were measured as pulmonary artery diastolic pressures if this was within $\pm 3 \mathrm{~mm} \mathbf{~ H g}$ of the pulmonary capillary wedge pressure. The heart rate was monitored from a continuously recorded electrocardiogram. Peripheral blood pressure was measured by sphygmomanometer cuff. Vascular resistance, stroke volume, and stroke work were calculated by conventional means.

\section{DRUG ADMINISTRATION}

This was an open study with three phases (fig 1).

Phase 1.-A dose titration at infusion rates of 0.5 , $1 \cdot 0,2 \cdot 0$, and $4.0 \mu \mathrm{g} / \mathrm{kg} / \mathrm{min}$. The dose was increased every 15 minutes until an adequate clinical and haemodynamic response was obtained.

Phase 2.-A 24 hour continuous infusion with a dose that satisfied one of the following criteria: an increase of $>30 \%$ in cardiac output or a decrease of $>30 \%$ in mean pulmonary wedge pressure or pulmonary diastolic pressure. During the 24 hour infusion period the dose of dopexamine was increased or reduced according to the clinical condition of the patient.

Phase 3.-Control readings were taken two hours

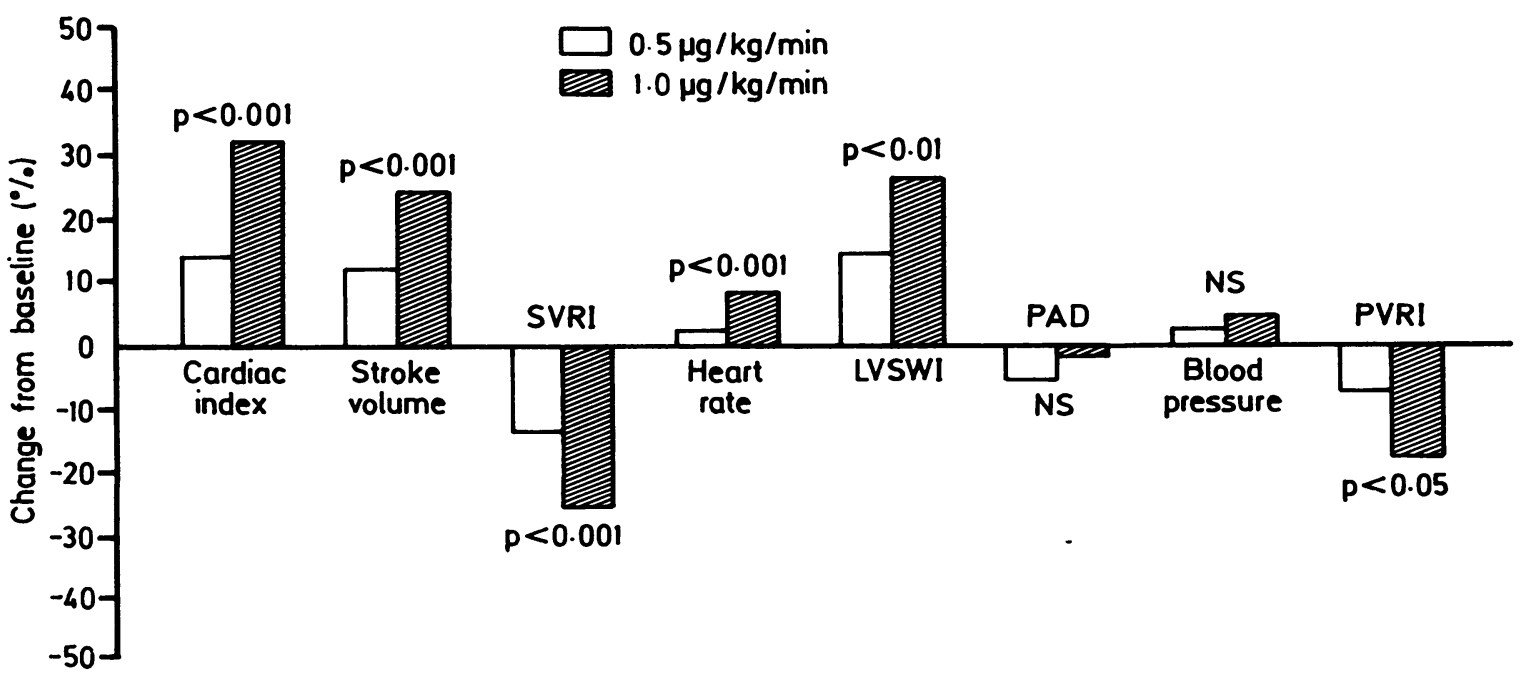

Fig 2 Effects of dopexamine hydrochloride 0.5 and $1.0 \mu \mathrm{g} / \mathrm{kg} / \mathrm{min}$ on haemodynamic variables during the initial dose titration (percent change from control). SVRI, systemic vascular resistance index; LVSWI, left ventricular stroke work index; $P A D$, pulmonary artery diastolic pressure; PVRI, pulmonary vascular resistance index. 
Table 3 Haemodynamic data from the long term infusion (phase 2)

\begin{tabular}{|c|c|c|c|c|c|c|c|c|c|}
\hline \multirow[b]{2}{*}{ Haemodynamic variable } & \multirow[b]{2}{*}{ Control } & \multicolumn{5}{|c|}{ Time into infusion } & \multirow{2}{*}{$\begin{array}{l}\text { Standard } \\
\text { deviation }\end{array}$} & \multirow[b]{2}{*}{ Significance } & \multirow{2}{*}{$\begin{array}{l}\text { जS } \\
10.0 \bar{\sigma} \\
\text { (0) }\end{array}$} \\
\hline & & 4 & 8 & 12 & 20 & 24 & & & \\
\hline $\begin{array}{l}\text { Heart rate (beats/min) } \\
\text { Systolic blood pressure (mm Hg) } \\
\text { Diastolic blood pressure (mm Hg) } \\
\text { Mean blood pressure (mm Hg) } \\
\text { Systolic pulmonary artery pressure }\end{array}$ & $\begin{array}{r}76 \\
123 \\
73 \\
90\end{array}$ & $\begin{array}{r}90 \\
133 \\
77 \\
95\end{array}$ & $\begin{array}{r}90 \\
131 \\
76 \\
94\end{array}$ & $\begin{array}{r}89 \\
129 \\
76 \\
93\end{array}$ & $\begin{array}{r}91 \\
124 \\
71 \\
88\end{array}$ & $\begin{array}{r}93 \\
125 \\
75 \\
92\end{array}$ & $\begin{array}{l}4 \cdot 44 \\
6 \cdot 31 \\
3 \cdot 96 \\
4 \cdot 05\end{array}$ & $\begin{array}{l}<0.001 \\
<0.001 \\
<0.01 \\
<0.001\end{array}$ & 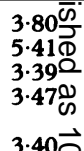 \\
\hline $\begin{array}{l}(\mathrm{mm} \mathrm{Hg}) \\
\text { Diastolic pulmonary artery pressure }\end{array}$ & 32 & 32 & 32 & 34 & 30 & 31 & 3.77 & NS & \\
\hline $\begin{array}{l}\text { (mm Hg) } \\
\text { Mean pulmonary artery pressure }\end{array}$ & 16 & 16 & 16 & 16 & 15 & 15 & $2 \cdot 18$ & NS & \\
\hline $\begin{array}{l}\text { (mm Hg) } \\
\text { Central venous pressure }\left(\mathrm{mm} \mathrm{Hg}^{\mathrm{H}}\right) \\
\text { Cardiac output }\left(1 / \mathrm{min}^{-1}\right. \\
\text { Cardiac index }\left(1 \mathrm{~min}^{-1} \mathrm{~m}^{-2}\right) \\
\text { Stroke volume index }\left(\mathrm{ml} \mathrm{beat}^{-1} \mathrm{~m}^{-2}\right) \\
\text { Systemic yascular resistance index }\end{array}$ & $\begin{array}{l}21 \\
6 \\
4 \cdot 03 \\
2 \cdot 16 \\
28 \cdot 6\end{array}$ & $\begin{array}{l}21 \\
6 \\
5 \cdot 99 \\
3 \cdot 22 \\
35 \cdot 7\end{array}$ & $\begin{array}{l}21 \\
6 \\
5 \cdot 92 \\
3 \cdot 16 \\
35 \cdot 0\end{array}$ & $\begin{array}{l}22 \\
6 \\
5 \cdot 61 \\
3 \cdot 01 \\
33 \cdot 7\end{array}$ & $\begin{array}{l}20 \\
6 \\
5 \cdot 84 \\
3 \cdot 13 \\
34 \cdot 5\end{array}$ & $\begin{array}{l}20 \\
5 \\
5 \cdot 70 \\
3 \cdot 07 \\
33 \cdot 0\end{array}$ & $\begin{array}{l}2 \cdot 42 \\
1 \cdot 22 \\
0 \cdot 432 \\
0 \cdot 243 \\
2 \cdot 86\end{array}$ & $\begin{aligned} & \text { NS } \\
& \text { NS } \\
&<0.001 \\
&<0.001 \\
&<0.001\end{aligned}$ & $\begin{array}{l}2.18 \stackrel{3}{ } \\
1.09 \\
0.37 \bar{్} \\
0.208 \\
2.450\end{array}$ \\
\hline $\begin{array}{l}\text { (units } / \mathrm{m}^{-2} \text { ) } \\
\text { Left ventricular stroke work }\end{array}$ & $40 \cdot 7$ & $28 \cdot 2$ & $29 \cdot 3$ & $30 \cdot 3$ & $26 \cdot 7$ & $30 \cdot 1$ & $3 \cdot 45$ & $<0.001$ & $3 \cdot 11 \stackrel{+0}{0}$ \\
\hline index $\left(g \times m / m^{2}\right)$ & $29 \cdot 3$ & $39 \cdot 2$ & $38 \cdot 7$ & $35 \cdot 4$ & $34 \cdot 8$ & $35 \cdot 0$ & $4 \cdot 22$ & $<0.001$ & $3 \cdot 62$ 윽 \\
\hline
\end{tabular}

LSD, least significant difference.

after the end of the infusion. The dose titration performed in phase 1 was then repeated.

Haemodynamic data were recorded at $-20 \mathrm{~min}$ utes, -5 minutes and immediately before the dopexamine infusion and every 15 minutes during the dose titration (before the dose was increased). During the long term infusion, data were recorded at $\mathbf{3 0}$ minutes and at $1,2,3,4,8,12,20$, and 24 hours.

\section{STATISTICAL METHODS AND ANALYSIS}

Dose titrations were analysed by two way analysis of variance with the dose and patient as factors. Where there was a significant treatment effect, paired data were compared by the least significant difference method.
A two way analysis of variance was also used analyse the continuous infusion but with time and the patient as factors.

The two controls and the two dose titrations were compared by a paired $t$ test.

All statistical tests were two tailed and a p value of $<0.05$ was regarded as significant.

\section{Results}

FIRST DOSE TITRATION (PHASE 1)

Data recorded during the initial dose titration we $\overrightarrow{\overrightarrow{2}}$ analysed to assesss the short term effect (table 27 During this dose titration all 15 patients received the lowest infusion rate $(0.5 \mu \mathrm{g} / \mathrm{kg} / \mathrm{min}), 12$ patienits

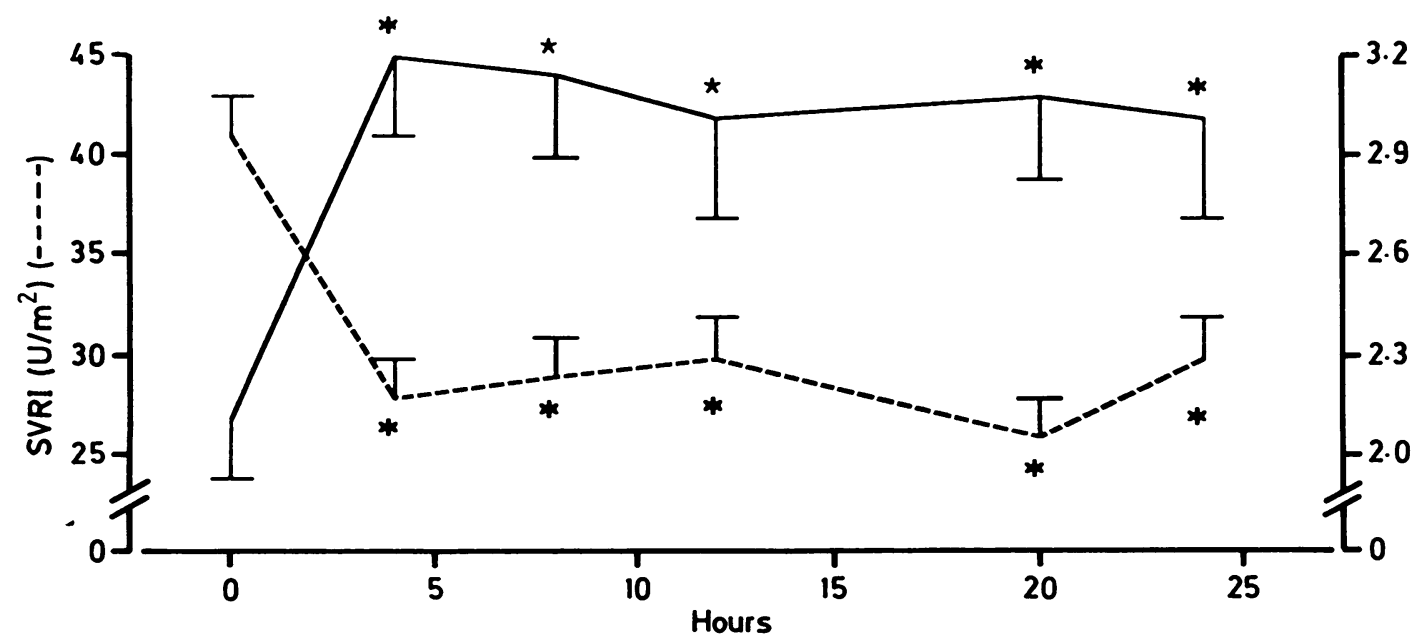

Fig 3 Effects (mean (SEM)) of dopexamine hydrochloride during the long term infusion on systemic vascular resistance index and cardiac index. * Significantly different from baseline values. 
Table 4 Haemodynamic data from the second dose titration (phase 3)

\begin{tabular}{|c|c|c|c|c|c|c|}
\hline \multirow[b]{2}{*}{ Haemodynamic variable } & \multicolumn{3}{|c|}{ Infusion rate $(\mu g / \mathrm{kg} / \mathrm{min})$} & \multirow{2}{*}{$\begin{array}{l}\text { Standard } \\
\text { deviation }\end{array}$} & \multirow[b]{2}{*}{ Significance $(p)$} & \multirow{2}{*}{$\begin{array}{l}L S D \\
(0.05)\end{array}$} \\
\hline & 0 & 0.5 & $1 \cdot 0$ & & & \\
\hline $\begin{array}{l}\text { Heart rate (beat/min) } \\
\text { Systolic blood pressure (mm Hg) } \\
\text { Diastolic blood pressure }(\mathrm{mm} \mathrm{Hg}) \\
\text { Mean blood pressure }(\mathrm{mm} \mathrm{Hg}) \\
\text { Systolic pulmonary artery pressure }(\mathrm{mm} \mathrm{Hg}) \\
\text { Diastolic pulmonary artery pressure }(\mathrm{mm} \mathrm{Hg}) \\
\text { Mean pulmonary artery pressure }(\mathrm{mm} \mathrm{Hg}) \\
\text { Central venous pressure (mm } \mathrm{Hg}) \\
\text { Cardiac output }\left(1 / \mathrm{min}^{-}\right) \\
\text {Cardiac index }\left(1 \mathrm{~min}^{-1} \mathrm{~m}^{-2}\right) \\
\text { Stroke volume index }\left(\mathrm{ml}^{-1} \text { beat }{ }^{-1} \mathrm{~m}^{-2}\right) \\
\text { Systemic vascular resistance index }\left(\mathrm{units} / \mathrm{m}^{-2}\right) \\
\text { Left ventricular stroke work index }\left(\mathrm{gxm} / \mathrm{m}^{2}\right)\end{array}$ & $\begin{array}{r}89 \\
119 \\
76 \\
90 \\
30 \\
16 \\
20 \\
6 \\
4 \cdot 26 \\
2 \cdot 34 \\
26 \cdot 9 \\
37 \cdot 7 \\
27 \cdot 5\end{array}$ & $\begin{array}{c}93 \\
122 \\
73 \\
89 \\
30 \\
15 \\
20 \\
6 \\
4 \cdot 71 \\
2 \cdot 60 \\
28 \cdot 6 \\
33 \cdot 5 \\
29 \cdot 0\end{array}$ & $\begin{array}{l}95 \\
126 \\
73 \\
90 \\
30 \\
15 \\
20 \\
5 \\
5 \cdot 23 \\
2 \cdot 88 \\
30 \cdot 9 \\
31 \cdot 1 \\
31 \cdot 7\end{array}$ & $\begin{array}{l}2.06 \\
3.59 \\
3.99 \\
3.11 \\
1.13 \\
1.16 \\
1.09 \\
1.155 \\
0.347 \\
0.179 \\
2.22 \\
2.58 \\
2.67\end{array}$ & $\begin{array}{c}<0.001 \\
<0.01 \\
N S \\
N S \\
N S \\
N S \\
N S \\
N S \\
<0.001 \\
<0.001 \\
<0.001 \\
<0.001 \\
<0.01\end{array}$ & $\begin{array}{l}1.93 \\
3.37 \\
3.75 \\
2.92 \\
1.06 \\
1.09 \\
1.02 \\
1.085 \\
0.326 \\
0.168 \\
2.09 \\
2.43 \\
2.51\end{array}$ \\
\hline
\end{tabular}

LSD, least significant difference.

received $1.0 \mu \mathrm{g} / \mathrm{kg} / \mathrm{min}$, four patients received $2.0 \mu \mathrm{g} /$ $\mathrm{kg} / \mathrm{min}$, and one patient $4.0 \mu \mathrm{g} / \mathrm{kg} / \mathrm{min}$. So we compared the control values with the first two dose points $(0.5$ and $1.0 \mu \mathrm{g} / \mathrm{kg} / \mathrm{min})$. This analysis is based on data from 12 patients.

The systemic vascular resistance index was significantly reduced by $13 \%$ for $0.5 \mu \mathrm{g} / \mathrm{kg} / \mathrm{min}$ and by $25 \%$ for $1.0 \mu \mathrm{g} / \mathrm{kg} / \mathrm{min}$ (fig 2). Both doses produced significant increases in cardiac index of $15 \%$ and $32 \%$ respectively. Similarly, stroke index increased significantly by $12 \%$ and $23 \%$. Heart rate was not significantly changed at $0.5 \mu \mathrm{g} / \mathrm{kg} / \mathrm{min}$ (increase of 2 beats $/ \mathrm{min}$ ). The small increase of 7 beats $/ \mathrm{min}$ at the 1 $\mu \mathrm{g} / \mathrm{kg} / \mathrm{min}$ dose was, however, statistically significant. There was no change in diastolic or mean arterial blood pressure, but the systolic blood pressure rose significantly by $4 \%$ and $5 \%$ respectively. Left ventricular filling pressure was not affected.

\section{LONG TERM INFUSION (PHASE 2)}

The dose of dopexamine that produced the best haemodynamic response was chosen for the long term infusion.

One patient was withdrawn after the first dose titration because of chest pain and tachycardia. The infusion was stopped after 3 hours in one patient (technical failure), after four hours in one patient (chest pain), and after 22 hours in one patient (patient's request), and these patients are excluded from the statistical analysis. Data recorded at baseline, 4, 8, 12, 20 and 24 hours were compared (table 3).

A comparison of tables 2 and 3 shows that the differences between baseline values and $1.0 \mu \mathrm{g} / \mathrm{kg} /$ min during the dose titration and those between baseline values and the four hour time point are not the same. Additionally, baseline values in table 2 are slightly different from those in table 3 . There are two reasons for this. Firstly the two populations are slightly different; the twelve patients who received the 0.5 and $1.0 \mu \mathrm{g} / \mathrm{kg} / \mathrm{min}$ infusion rates are not the same as the eleven for whom data were available for all time points on the $\mathbf{2 4}$ hour analysis. Secondly, table 3 includes data from patients who subsequently went on to receive infusion rates higher than $10 \mu \mathrm{g} /$ $\mathrm{kg} / \mathrm{min}$.

Cardiac index, stroke volume index, left ventricular stroke work index, and heart rate were significantly higher than baseline values at all time points and the systemic vascular resistance index was lower (fig 3). Systolic, diastolic, and mean blood pressure response at 4,8 , and 12 hours was significantly different from baseline. Left ventricular filling pressure was not affected.

\section{SECOND DOSE TITRATION (PHASE 3)}

During the second dose titration cardiac index $(11 \%$ and $23 \%$ ), stroke volume index $(6 \%$ and $15 \%)$ and systolic blood pressure $(5 \%)$ were significantly higher than baseline for the 0.5 and $1 \mu \mathrm{g} / \mathrm{kg} / \mathrm{min}$ doses (table 4). As during the first dose titration the heart rate was not significantly changed at the lower dose but the small increase of 7 beats $/ \mathrm{min}$ at the higher dose was statistically significant. The systemic vascular resistance index decreased significantly.

Baseline values for cardiac index and heart rate were higher during phase 3 than during phase 1 . The responses to the two doses of dopexamine during the two phases were not significantly different (fig 4). This indicates that no tolerance had developed to the effect of dopexamine.

\section{SIDE EFFECTS}

Three patients experienced unusual symptoms during the study. In patient 3 angina developed at the 1 $\mu \mathrm{g} / \mathrm{kg} / \mathrm{min}$ dose; it disappeared when the dose was reduced to $0.5 \mu \mathrm{g} / \mathrm{kg} / \mathrm{min}$. Patient 12 showed increases in heart rate and blood pressure and also 


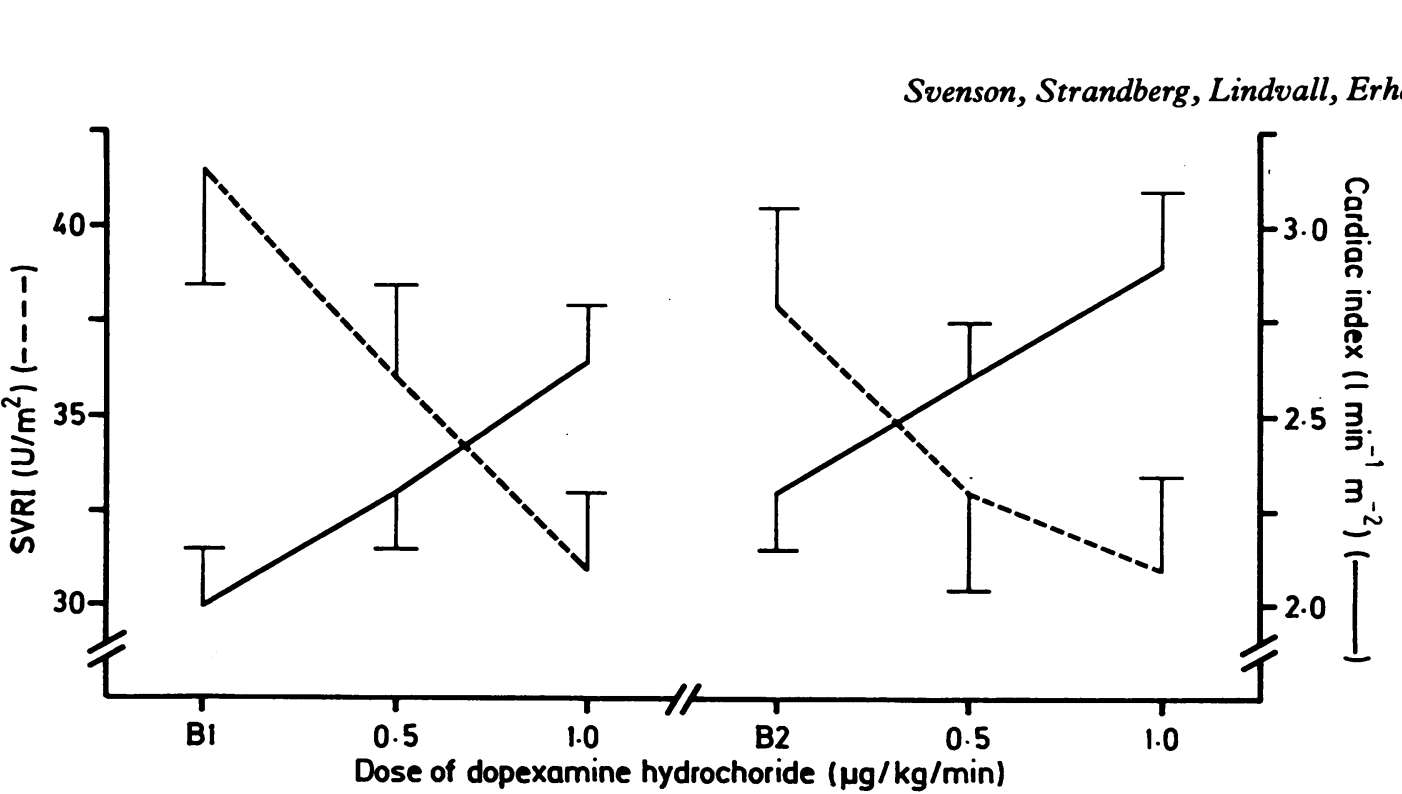

Fig 4 A comparison of the effect (mean (SEM)) of two dose titrations on systemic vascular resistance index and cardiac index shows no significant differences between the responses to the two doses of dopexamine hydrochloride on the two occasions $B 1$, baseline value for first dose titration; B2, baseline value for second dose titration.

developed chest pain at the $0.5 \mu \mathrm{g} / \mathrm{kg} / \mathrm{min}$ dose (during dose titration), and patient 5 had angina at the $0.5 \mu \mathrm{g} / \mathrm{kg} / \mathrm{min}$ dose (after three hours of the long term infusion). The infusion was terminated in patients 5 and 12.

\section{Discussion}

We studied the haemodynamic effects of dopexamine during dose titration in patients with mild to moderate heart failure after myocardial infarction. We also investigated whether any of the effects shown during dose titration could be maintained during a 24 hour period of continued infusion and whether tolerance developed. As this was the first trial of dopexamine in patients with acute myocardial infarction an open study was considered to be safer. The initial dose titration was important because the haemodynamic effect of dopexamine in human volunteers and patients with chronic heart failure would not necessarily be the same in acute heart failure. This is because dopexamine is a potent, competitive inhibitor of the neuronal uptake of catecholamines and the effects might be expected to be more pronounced in patients with myocardial infarction in whom sympathetic tone is high. In fact, the doses used in this study are lower than in studies of dopexamine in patients with chronic heart failure. ${ }^{1820}$ The situation in acute failure after myocardial infarction is, however, complicated and an increased filling pressure in the left ventricle may not always indicate true failure, but only an altered state of compliance of the left ventricular wall. Thess situation may be entirely different from that of chronic failure in which peripheral resistance os increased and cardiac output reduced. A difference the number of as well as sensitivity of the $\beta$ receptoss of the heart between patients with heart failure aftir acute myocardial infarction and those with chrongc heart failure could be another reason why our patients responded at lower dose levels.

We found that dopexamine improved haemody amic function after myocardial infarction. Cardiac output and stroke volume were increased and afterload was reduced. This finding is consistent with the known pharmacology of dopexamine and toina large extent is attributable to considerabige vasodilator activity, primarily arterial, reducing sy\&temic vascular resistance. ${ }^{14}$ 15 During the long term infusion the initial effects were well sustained. Over this period there were slight and apparently sponta⿳亠丷⿵冂丶 eous changes in systemic vascular resistance, bloof pressure, and heart rate. This could be explained by an initial high level of circulating catecholamines and high sympathetic tone causing peripheral vasocoystriction. With time the effects become attenuated as the endogenous catecholamine concentrations fell and the reduction in afterload was effected byọa reduction in endogenous adrenergic stimulation while the $\beta_{2}$ stimulant effect of the infusion wess maintained. The increase in heart rate during the e $\overrightarrow{\mathrm{g} d}$ of the 24 hour infusion may therefore be mediated toy the baroreceptor. 
Three patients had tachycardia associated with angina. When dopexamine was stopped or reduced both symptoms resolved. Although angina pectoris is a common symptom after acute myocardial infarction, the increase in heart rate preceding the anginal episodes means that the tachycardia is likely to be the precipitating event. Whether the positive inotropic effect of dopexamine is important in this respect is unclear. The increase in heart rate seen in some of our patients could, however, make dopexamine less suitable in patients with remaining ischaemia. A careful dose titration with close monitoring of heart rate and symptoms is therefore recommended in patients with post-infarction failure.

Development of tolerance after treatment with $\beta$ adrenergic agonists is associated with receptor down regulation. This phenomenon seems to result from both a decrease in the number of as well as a desensitisation of the $\beta$ receptors. ${ }^{22-25}$ Although dopexamine has a weak $\beta_{1}$ effect the reproducibility of the dose response curve at the second dose titration indicates that tolerance did not develop during a 24 hour period. This is further supported by the persistence of the effects seen initially during the long term infusion.

Although cardiac output was low in most of our patients, they were only in mild heart failure. As yet we do not know whether dopexamine can produce useful effects in more advanced heart failure including patients with very high filling pressures. Our patients were investigated in rest only; during exercise the haemodynamic changes caused by dopexamine may be different.

Additional studies are needed to confirm our observations and the possible role of dopexamine in the short term treatment of heart failure.

This study was supported by grants from the Swedish National Association against Heart and Chest diseases and Fisons Pharmaceuticals.

\section{References}

1 Weber KT, Janick JS, Russel RO. Identification of high risk subjects in myocardial infarction. Am J Cardiol 1978;41:197-203.

2 Cohn JN, Franciosa JA, Francis GS, et al. Effects of short term infusion of sodium nitroprusside on mortality rate in acute myocardial infarction complicated by left ventricular failure. Results of a Veterans Administration Co-operative Study. $N$ Engl J Med 1982;206:1129-35.

3 Wolffenbuttel BHR, Verdouw PD, Scheffer MG, Bom HPA, Bijleveld RE, Hugenholtz PG. Significance of haemodynamic variables in coronary care unit for prediction of survival after acute myocardial infarction. Br Heart J 1983;50:266-72.

4 Gillespie TA, Ambos HD, Sobel BE, Roberts R. Effects of dobutamine in patients with acute myocardial infarction. Am J Cardiol 1977;39:588-94.

5 Keung ECH, Siskind SJ, Sonnenblick EH, Ribner K, Swartz WJ, Lejemtel TH. Dobutamine therapy in acute myocardial infarction. JAMA 1981;245: 144-6.

6 Beregovich J, Bianchi C, Ruhler S, Comnitz E, Cagin $H$, Lewitt B. Dose related hemodynamic and renal effects of dopamine in congestive heart failure. $\mathrm{Am}$ Heart J 1974;85:550-7.

7 Reiz S, Friedman A, Häggmark S. Hemodynamic and cardio-metabolic effects of prenalterol in patients with acute myocardial infarction and shock. Acta Med Scand 1981;25:235-9.

8 Nelson GIC, Verma SP, Hussain M, et al. A randomized study of the hemodynamic changes induced by veno-dilatation and arterial dilatation singly and together in left ventricular failure complicating acute myocardial infarction. $J$ Cardiovasc Pharmacol 1984;6:331-8.

9 Chatterjee K, Parmley W. Vasodilator therapy for acute myocardial infarction and chronic congestive heart failure. J Am Coll Cardiol 1983;1:133-53.

10 Cohn J, Franciosa JA. Selection of vasodilator, inotropic or combined therapy for the management of heart failure. Am J Med 1978;65:181-8.

11 Kupper W, Waller D, Hanrath $P$, Bleifeld W. Hemodynamic and cardiac metabolic effects of inotropic stimulation with dobutamine in patients with coronary artery disease. Eur Heart $J$ 1982;3: 29-34.

12 Goldberg LI, Hsieh YY, Resnekov L. Newer cathecolamines for treatment of heart failure and shock: an update on dopamine and a first look at dobutamine. Prog Cardiovasc Dis 1977;19:327-40.

13 Taylor SH, Silke B, Nelson GIC. Principles of treatment of left ventricular failure. Eur Heart $J$ 1982;3 (suppl D):19-43.

14 Brown RA, Farmer JB, Hall JC, et al. FPL 60278 (dopexamine): actions at pre- and post-junctional dopamine receptors and at alfa- and beta-adrenoreceptors [Abstract]. Br J Pharmacol 1984;81 (suppl):120P.

15 Brown RA, Dickson J, Framer JB, et al. Dopexamine: a novel agonist at peripheral dopamine receptors and

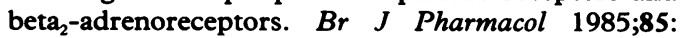
599-608.

16 Brown RA, Farmer JB, Hall JC, Humphries RG, O'Connor SE, Smith GW. The effects of dopexamine on the cardiovascular system of the dog. $\mathrm{Br} J$ Pharmacol 1985;85:609-19.

17 Yaski BE, Wijns W, Foulds R, Serruys PW. The hemodynamic and myocardial effects of dopexamine.

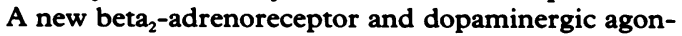
ist. Br J Clin Pharmacol 1986;21:393-400.

18 Svenson G, Sjögren A, Erhardt L. Short term hemodynamic effects of dopexamine in patients with chronic congestive heart failure. Eur Heart $J$ 1986; 7:697-703.

19 Bayliss J, Thomas L, Poole-Wilson P. Acute hemodynamic and neuroendocrine effects of dopexamine, a new vasodilator for the treatment of heart failure: compar- 
ison with dobutamine, captopril, and nitrate. J Cardiovasc Pharmacol 1987;9:551-4.

20 Dawson JR, Thompson DS, Signy M, et al. Acute hemodynamic and metabolic effects of dopexamine, a new dopaminergic receptor agonist in patients with chronic heart failure. Br Heart J 1985;54:313-20.

21 Bass AS, Kohli JD, Lubbers NL, Goldberg LI. Cardiovascular evaluation of dopexamine, an unusual dopamine receptor agonist [Abstract]. Clin Res 1986;34:941.

22 Bristow MR, Ginsburg R, Minobe W, et al. Decreased catecholamine sensitivity and beta-adrenergic-recep- $C$. tor density in failing human hearts. $N$ Engl $J$ Med 1982;307:205-11.

23 Harden TK. Agonist-induced densensitization of the beta-adrenergic receptor-linked adenylate cyclase. Pharmacol Rev 1983;35:5-32.

24 Heinsimer JA, Lefkowitz RJ. The beta-adrenergic $\mathbb{D}$ receptor in heart failure. Hosp Pract 1983;18:103-25.

25 Unverferth DV, Blanford M, Kates RE, Leier CV. Tolerance to dobutamine after a 72 hour continuous $\vec{O}$ infusion. Am J Med 1980;69:262-6. 